\title{
Comparison of electrophoresis, isoelectric focusing, and immunodiffusion in determinations of cow's and goat's milk in Serra da Estrela cheeses
}

\author{
L Amigo 1, M Ramos 1, L Calhau 2, M Barbosa 2 \\ ${ }^{1}$ CSIC-Instituto de Fermentaciones Industriales, 28006 Madrid, Spain; \\ 2 LNETI-Departamento de Tecnologia das Indústrias Alimentares, 1900 Lisboa, Portugal
}

(Received 8 November 1990; accepted 19 September 1991)

\begin{abstract}
Summary - A comparative study of electrophoresis (PAGE), isoelectric focusing (IEF), and radial immunodiffusion (RID) in determinations of cow's and goat's milks in Serra da Estrela cheeses was carried out. The qualitative results were the same for all 3 methods, except for 2 samples in which the immunological method failed to detect cow's milk and 3 samples in which it failed to detect goat's milk. Adulteration mainly took the form of the addition of goat's milk. The quantitative results obtained by electrophoresis and isoelectric focusing did not show any significant differences $(P<$ 0.05).
\end{abstract}

PAGE and IEF whey proteins / cow's and goat's milk detection / immunodiffusion / Serra da Estrela cheese

Résumé - Comparaison entre l'électrophorèse, l'isoélectrofocalisation et l'immunodiffusion radiale pour la détermination des laits de vache et de chèvre dans les fromages uSerra da Estrelan. Une étude comparative de trois méthodes - électrophorèse (PAGE), isoélectrofocalisation (IEF) et immunodiffusion radiale (RID) - a été réalisée pour la détermination des laits de vache et de chèvre dans les fromages "Serra da Estrela". Les résultats qualitatifs ont été les mêmes pour les trois méthodes, à l'exception de deux échantillons pour lesquels le résultat de l'immunodiffusion radiale a été négatif pour le lait de vache et de trois autres échantillons pour lesquels les résultats ont été négatifs pour le lait de chèvre. L'adultération la plus fréquente a été observée avec le lait de chèvre. Les résultats quantitatifs calculés pour l'électrophorèse (PAGE) et l'isoélectrofocalisation (IEF) ne sont pas statistiquement différents $(\mathrm{r}=0,73 ; \mathrm{P}<0,05)$.

PAGE et IEF de lactosérums / dosage du lait de vache et de chèvre / immunodiffusion radiale / fromage "Serra da Estrela" 


\section{INTRODUCTION}

The production of ewe's and goat's milk has gained considerable economic importance in certain Mediterranean countries as a result of widespread acceptance of traditional cheeses.

Serra da Estrela cheese is one of the most important ewe's milk cheeses made by the farmers in the mountain area of the same name in Portugal, using raw milk with cardo (Cynara cardunculus) as rennet. The economic importance of Serra da Estrela cheese has been recognized, and its production estimated at 2500 tons, which represents $5 \times 10^{9} \mathrm{Esc}$ (PTE), an important source of wealth for the rural population.

This cheese is mainly produced in vitlages situated within the Serra da Estrela Natural Park, although the region demarcated for its production (Law No 42/85) includes some areas outside the park. These cheeses are still marketed without any certified labeling to protect their origin and quality, which encourages adulteration (Barbosa, 1990).

Milk of other species (goats and cows) is frequently detected, resulting in a loss of genuineness as in some areas the farmers have a few goats within their sheep flocks and in other areas one or 2 cows to provide milk for home consumption.

A number of researchers have proposed a variety of analytical methods for detecting mixtures of milk from different species in cheeses. Such analytical methods are based chiefly on immunological (Levieux, 1978; Aranda et al, 1988; Garcia et al, 1989) and electrophoretic techniques (Krause and Belitz, 1985; Ramos and Juarez, 1986; Addeo et al, 1990). The immunological technique of radial immunodiffusion (RID) proposed by Levieux (Journal Officiel de la République Française, 1978) has been used to detect cow's and goat's milk in Serra da Estrela cheese since 1978 with good results (Barbosa and Goncalves, 1986).

In recent years various methods based on electrophoretic analysis of the whey proteins have been developed (Ruiz and Santillana, 1986; Addeo et al, 1989; Amigo et al, 1989; Rispoli and Saugues, 1989). In a study on the effect of various technological parameters in electrophoretic detection of cow's milk in ewe's milk cheeses (Amigo et al, 1991) we have observed that the vegetal rennet exerted a greater proteolytic action than animal rennet on whey proteins.

The aim of this study was to compare an immunological and 2 electrophoretic methods for the determination of goat's and cow's milk in Serra da Estrela cheese.

\section{MATERIALS AND METHODS}

A total of 52 Serra da Estrela cheeses were collected at regional cheese fairs in 1987 and 1988. The following physicochemical analyses were performed (the method employed is given in brackets): $\mathrm{pH}$, acidity (AOAC, 16.276), dry matter (NP (Portuguese Standard), 3544), fat (NP, 2105), $\mathrm{NaCl}$ (AOAC, 16.272), ash (AOAC, 16.267), and total and soluble nitrogen (Kjeldahl).

\section{Preparation of whey proteins}

The whey proteins were separated from the cheeses by precipitation with $\mathrm{HCl}$ to $\mathrm{pH} 4.6$. The fraction soluble at $\mathrm{pH} 4.6$ was analyzed by electrophoresis, isoelectric focusing, and radial immunodiffusion. Protein bands were identified using bovine serum albumin (BSA) and bovine $\alpha$ lactalbumin $(\alpha-\mathrm{La}), \beta$-lactoglobulin $A(\beta-\mathrm{Lg} A)$, and $\beta$-lactoglobulin $B(\beta-\operatorname{Lg} B)$, from Sigma Chemical Company (St Louis, MO, USA) and caprine and ovine $\alpha-\mathrm{La}$ and $\beta$-Lg prepared at the laboratory following the method of Fox et al (1967). 


\section{Radial immunodiffusion}

Radial immunodiffusion was carried out according to the Levieux method, described in the Journal Officiel de la République Française $(1978)^{*}$. The plates were prepared at LNETIDTIA, using the methodology previously described by Levieux (1980). The antiserum was kindly offered by Levieux.

\section{Polyacrylamide gel electrophoresis}

Electrophoresis of the whey proteins was performed by applying the method of Amigo et al (1986). The acrylamide concentration was $T=$ $9.4 \%$ and $C=4.25 \%$. Gels were stained with Coomassie blue R-250 (Winter et al, 1977).

\section{Isoelectric focusing}

Isoelectric focusing of the whey proteins was performed by applying the method of Ruiz and Santillana (1986) using LKB ampholine PAG plates with a pH range of 3.5-9.5 measuring $245 \mathrm{~mm} \times 100 \mathrm{~mm} \times 1 \mathrm{~mm}, \mathrm{~T}=5 \%$ and $\mathrm{C}=3 \%$. The electric conditions were $1500 \mathrm{~V}, 50 \mathrm{~mA}$, and $10 \mathrm{~W}$ (maximum $150 \mathrm{~V} / \mathrm{cm}$ ) for $3 \mathrm{~h}$. The isoelectric points $(\mathrm{pl})$ were determined by interpolation from a pl/distance calibration curve constructed using standard markers; the $\mathrm{pH}$ readings were taken with a model 2117-111 LKB surface electrode at every $\mathrm{cm}$ of gel before staining.

\section{Quantitative determination}

PAGE and IEF gels were quantified by densitometric measurements at $600 \mathrm{~nm}$ using Shimadzu equipment consisting of a spectrophotometer with an integrator and graphic printing system (DR-2 Data Recorder).

Quantification was based on the measurement of peak height of the $\beta-\mathrm{Lg}$ from cow's, goat's, and ewe's milks.
Ewe's milk containing $10,20,30$ and $40 \%$ cow's or goat's milk was used for the calibration curves. Linear relationships were calculated for bovine $\beta$ - $\mathrm{Lg}$ /ovine $\beta-\mathrm{Lg}$ on the percentage of cow's milk and caprine $\beta$ - $\mathrm{Lg} / \mathrm{ovine} \beta$ - $\mathrm{Lg}$ on the percentage of goat's milk.

\section{RESULTS AND DISCUSSION}

Mean values for weight, $\mathrm{pH}$, acidity, dry matter, fat, $\mathrm{NaCl}$, ash, total nitrogen (TN), soluble nitrogen (SN), and a ripening coefficient (SN/TN.100) are shown in table I, along with the standard deviations, for the 52 samples of Serra da Estrela cheese aged for 30 to 45 days.

The results were comparable to those reported by Barbosa (1986) and indicate that variations in chemical composition are not a useful criterion for distinguishing cheeses made from blends of the milks of different species.

Table I. Physico-chemical analysis of 52 Serra da Estrela cheeses aged for $30-45$ days.

Analyse physicochimique de 52 fromages "Serra da Estrela" âgés de 30-45 jours.

\begin{tabular}{lrr}
\hline Parameters & Mean & Std Dev \\
\hline Weight (kg) & 1.267 & .199 \\
pH & 5.267 & .214 \\
Acidity (\% lactic acid) & .863 & .132 \\
Dry matter (DM) (\%) & 51.758 & 2.648 \\
Fat (\% DM) & 50.672 & 4.695 \\
NaCl (\% DM) & 4.487 & .958 \\
Ash (\% DM) & 8.164 & .999 \\
TN (\% DM) & 6.215 & .488 \\
SN (\% DM) & 2.424 & .305 \\
Ripening index & & \\
(SN/TN) $\times 100$ & 39.042 & 3.961 \\
\hline
\end{tabular}

\footnotetext{
- The method is marketed in France by the Sociéte François Hubert, 18800 Baugy, France
} 


\section{Qualitative results}

The qualitative results obtained by the 3 methods in 52 cheese samples are similar; only in 3 samples and 2 samples respectively goat's milk and cow's milk was undetected by the RID method. This can probably be ascribed to difficulties in interpreting the results when non-specific precipitation halos are observed and is probably due to the special characteristics of these cheeses, which present very high levels of fat and protein degradation induced by the vegetable rennet used. The results for the 28 samples from 1988 were all similar. In a previous study on Manchego cheese, there were no qualitative differences between RID and electrophoretic method by detection of cow's and goat's milk (Amigo et al, 1989).

PAGE and IEF gave the same results for all the samples: $36.5 \%$ were genuine ewe's-milk cheeses, $52 \%$ contained goat's milk, and $9.6 \%$ contained both goat's and cow's milks mixed with the ewe's milk. One of the cheese $(2 \%)$ was made from cow's milk alone.

From the qualitative point of view the results with the 3 methods are comparable. RID is a simple and rapid procedure and did not need specialized equipment. For cheeses made with raw milk, like the Serra da Estrela cheese and having an "Appellation d'origine" it has the advantage of being used as a screening method that can be performed easily. PAGE and IEF have the advantage that cow's and goat's milk can be analyzed in the same analysis but on the other hand, they require specialized staff and equipment.

\section{Isoelectric focusing and electrophoresis of the whey proteins}

Figure 1 shows the isoelectrophoregrams for the whey proteins of cow's, ewe's, and

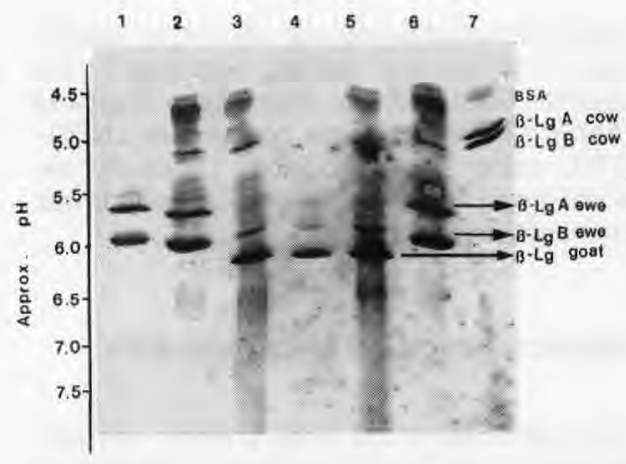

Fig 1. Isoelectrophoregrams of the whey proteins from cow's milk (7), ewe's milk $(2,6)$, and goat's milk $(3,5)$ and of the caprine $\beta$ lactoglobulins $(\beta-\mathrm{Lg})(4)$ and ovine $\beta-\operatorname{LgA}$ and $B$ (1).

Isoélectrophorégrammes des protéines solubles $d u$ lait de vache (7), du lait de brebis $(2,6)$ et du lait de chèvre $(3,5)$ ainsi que la $\beta$-lactoglobuline $(\beta-L g)$ caprine (4) et de la $\beta-L g$ A et $B$ ovine (1).

goat's milk as well as for the $\beta$ - $\mathrm{Lg}$ separated from the milks of these 3 species using the method of Fox et al (1967). The 2 bands in the ovine milk whey with a pl of 5.73 and 5.87 corresponded to the genetic variants A and B (Addeo et al, 1989; Amigo, 1989).

The differing isoelectric points of the bovine $\beta-\operatorname{Lg} A$ and $B$ (5.12 and 5.29, respectively) and the caprine $\beta-\mathrm{Lg}(6.06)$ constitute the basis for determining the presence of cow's milk and goat's milk in blends of milks. Ruiz et al (1986) and Rispoli and Saugues (1989) obtained similar isoelectrophoregrams, although they did not identify any of the whey proteins.

Figure 2 presents the isoelectrophoregram for the Serra da Estrela cheese samples. The isoelectrophoregrams are peculiar in that ovine $\alpha$-La was absent in $94 \%$ of the samples analyzed, and the BSA 


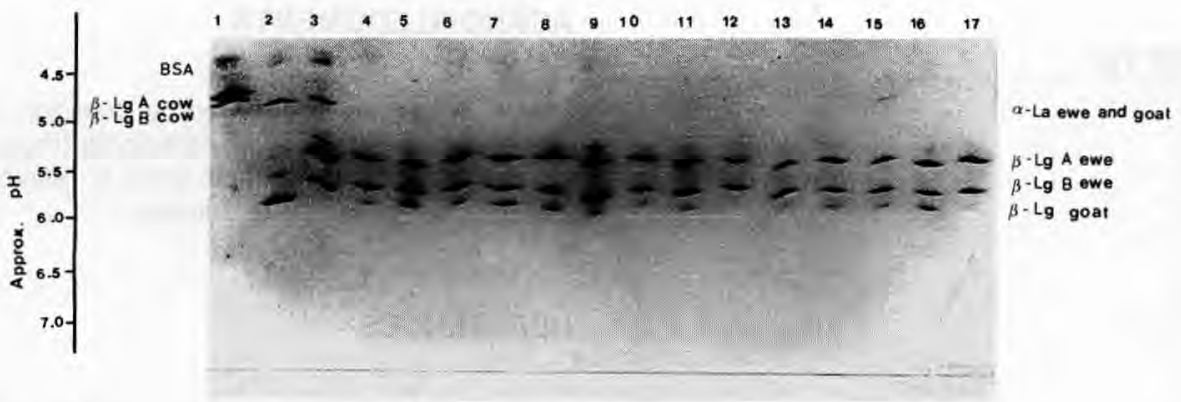

Fig 2. Isoelectrophoregrams of the whey proteins from cow's milk (1), goat's milk (2), and ewe's milk (3) and some samples of Serra da Estrela cheeses.

Isoélectrophorégrammes des protéines solubles du lait de vache (1), du lait de chèvre (2) et du lait de brebis (3) et de quelques échantillons de fromage "Serra da Estrela".

content was also low, the band for BSA being absent in $54 \%$ of the samples. These results were confirmed by electrophoresis (fig 3), in which, as described earlier by Amigo et al (1989), bovine $\beta-\mathrm{Lg} \mathrm{A}$ and B displayed greater electrophoretic mobility than ovine and caprine $\beta-\mathrm{Lg}$. Caprine $\beta-\mathrm{Lg}$ exhibited greater mobility than ovine $\beta-\mathrm{Lg}$.

The genetic variants of $\beta-\operatorname{Lg} A$ were detected in the samples containing cow's milk

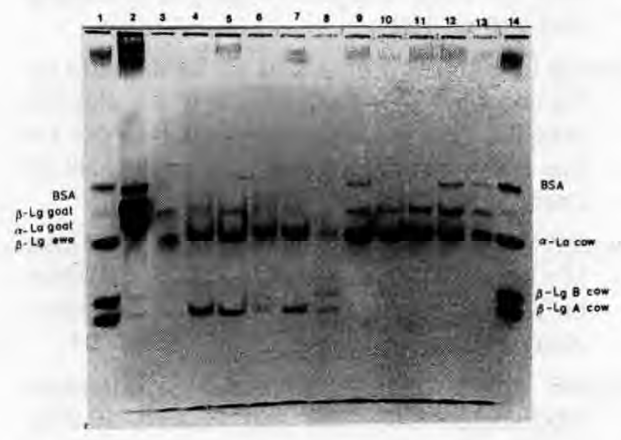

Fig 3. Electrophoregrams of the whey proteins from cow's milk $(1,14)$, goat's milk $(2)$, and some samples of Serra da Estrela cheeses.

Electrophorégrammes des protéines solubles du lait de vache $(1,14)$, du lait de chèvre (2) et de quelques échantillons de fromage "Serra da Estrela». by both PAGE and IEF, probably because a single cow to spike bulk ovine milk was used in the adulterations.

In a study carried out by Amigo et al (1991) on the influence of various technological parameters on the detection of cow's milk, vegetable rennet was found to have a high level of proteolytic activity and to degrade $\alpha$-La and BSA. Viera de Sá and Barbosa (1972) demonstrated that the proteolytic activity of cardo was higher than that of animal rennet. Barbosa et al (1976) used cardo to make Camembert cheese and obtained cheeses with a strong bitter flavor, indicative of the high degree of proteolysis induced by this type of rennet. Similar results have been reported when vegetable rennet was used in the manufacture of Italian cheeses (Barbosa et al, 1981).

\section{Quantitative determination of goat's milk by PAGE and IEF}

Figure 4 shows the percentages of goat's milk determined in 32 samples by PAGE and IEF. The correlation coefficient value is 0.73 . The dispersion of results obtained 


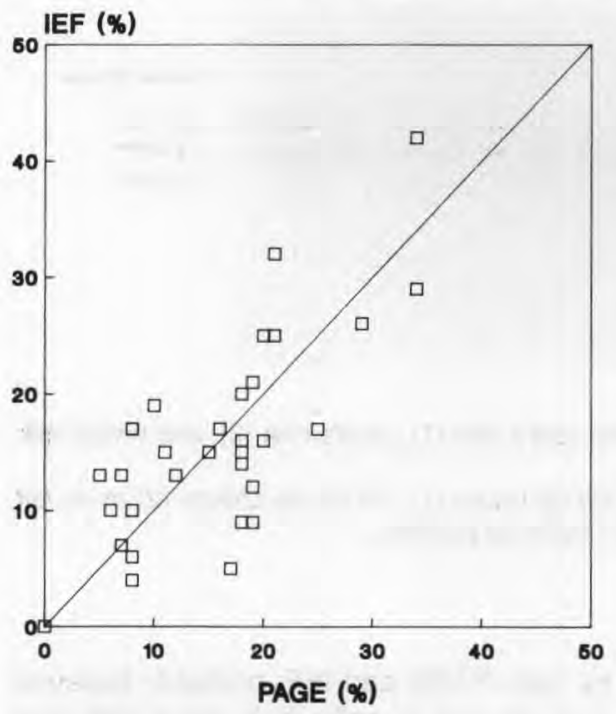

Fig 4. Percentage of goat's milk found in 32 samples of Serra da Estrela cheeses by electrophoresis (PAGE) and isoelectric focusing (IEF). Pourcentage de lait de chèvre déterminé par électrophorèse (PAGE) et isoélectrofocalisation (IEF) dans les 32 échantillons de fromage "Serra da Estrela".

by the 2 methods may be due to the error of each method. In a previous paper (Amigo et al, 1989) we carried out 5 replications of the PAGE analysis of a cheese sample containing $10 \%$ cow's milk. In that case we obtained a mean value of $8.58 \%$ for cow's milk with a coefficient of variation (CV) of $8.62 \%$.

Applying the "one-sample $t$-test" no significant differences were found between the percentage of goat's milk values determined by PAGE and IEF methods $(P<$ $0.05)$. The mean differences and the SD were -0.6 and $6.2 \%$ respectively.

\section{ACKNOWLEDGMENTS}

This work has been supported by Comision Interministerial de Ciencia y Technologia (Project No ALI-88-0299). The authors thank C Talavera and L Piñal for technical assistance.

\section{REFERENCES}

Addeo F, Moio L, Chianese L, Di Luccia A (1989) Detection of bovine milk in ovine milk or cheese by gel isoelectric focusing of $\beta$ lactoglobulin: applications and limitations. Ital $J$ Food Sci 1, 45-52

Addeo F, Moio L, Chianese L, Stingo C, Resmini P, Berner I, Krause I, Di Luccia A, Bocca A (1990) Use of plasmin to increase the sensitivity of the detection of bovine milk in ovine cheese by gel isoelectric focusing of $\gamma_{2}$ caseins. Milchwissenschaft 45, 708-711

Amigo L (1989) Estudio de la fraccion proteíca de leche de oveja, cabra y vaca. Criterios analíticos para la determinacion de mezclas de leche en quesos. Ph D Thesis, Universidad Autónoma de Madrid, Spain

Amigo L, Santamaría G, González de LLano D, Ramos M (1986) Polyacrylamide gel electrophoresis of whey proteins in cheeses made from milk in different species. In: Poster 39, XXII Int Dairy Congr, The Hague (Int Dairy Fed, ed) pp 152

Amigo L, Ibañez I, Fernández C, Santamaría G, Ramos M (1989) Comparison of an electrophoretic and an immunological method for the determination of goat and cow milk in cheese. Milchwissenschaft 44, 215-218

Amigo L, Ramos M, Martín-Alvarez PJ, Barbosa M (1991) Effect of technological parameters on electrophoretic detection of cow's milk in ewe's cheeses. J Dairy Sci 74, 1482-1491

AOAC (1975) Official Methods of Analyses. Washington DC, 12th edn 16.267, 16.272, 16.276

Aranda P, Oria R, Calvo M (1988) Detection of cow's milk in ewe's milk and cheese by an immunodotting method. J Dairy Res 55, 121-124 
Barbosa M (1986) Serra da Estrela cheese. Bull Int Dairy Fed 202, 133-134

Barbosa M (1990) Production and transformation of sheep milk in Portugal. The case of "Serra da Estrela" cheese. Options Méditerranéennes $\mathrm{A} 12, \mathrm{pp} 97$

Barbosa M, Gonçalvez I (1986) Detection of goat and cow milk in fresh ewe cheese using the radial immunodiffusion method. Bull Int Dairy Fed 202, 188-190

Barbosa M, Valles E, Vassal L, Mocquot G (1976) L'utilisation d'extrait de Cynara cardunculus, comme agent coagulant en fabrication de fromages à pâte molle et à pâte cuite. Lait 56, 1-17

Barbosa M, Corradini C, Battistotti B (1981) Cheese making experiments carried out on some Italian cheese with vegetable rennet from cardo Cynara cardunculus. Sci Tec Latt Casearia 32, 203-221

Fox PF, Holsinger VH, Posati LP, Pallansch MJ (1967) Separation of $\beta$-lactoglobulin from other milk serum proteins by trichloroacetic acid. J Dairy Sci 50, 1363-1367

García T, Martín R, Rodríguez E, Hernández PE, Sanz B (1989) Development of a cow's milk identification test (COMIT) for field use. J Dairy Res 56, 691-698

Journal Officiel de la République Française (1978) 1/6/1978, NX 4266. Annexe à l'arrêté du 29 mars 1978 relatif aux méthodes officielles d'analyse des laits et fromages de chèvre

Krause I, Belitz HD (1985) Differenzierung von Milchproteinen verschiedener Tierarten: Nachweis von Kuhmilch in Schaf, Ziege und Buffelmilch bzw kase. Lebensmittelchem $\mathrm{Ge}$ richtl Chem 39, 33-36
Levieux D (1978) Détection immunologique des mélanges de laits de diverses espèces. $X X$ Congr Int Lait Paris, 15 Sci Tech

Levieux D (1980) Heat denaturations of whey proteins: comparative studies with physical and immunological methods. Ann Rech Vét $11,89-97$

Norma Portuguesa No 2105 (1983)

Normal Portuguesa No 3544 (1987)

Ramos M, Juárez M (1986) Chromatographic, electrophoretic and immunological methods for detecting mixtures of milk from different species. Bull Int Dairy Fed 202, 175-190

Rispoli S, Saugues R (1989) Isoélectrofocalisation des lactosérums de fromages de mélange brebis-vache sur gel de polyacrylamide. Application à la recherche et au dosage du lait de vache dans les fromages de brebis. Lait 69, 211-229

Ruiz E, Santillana I (1986) Determinación de mezclas de leche de vaca, cabra y oveja por isoelectroenfoque en gel de poliacrilamida. Alimentaria 53, 55-64

Ruiz E, Santillana I, Yuste T (1986) Aplicación del isoelectroenfoque a la determinación de especies en quesos de mezcla. Comunicación 26, XXI Reunión Bienal de la Real Sociedad Española de Química, Santiago de Compostela, pp 553

Vieira de Sá F, Barbosa M (1972) Cheesemaking with a vegetable rennet from Cardo Cynara cardunculus. J Dairy Res 39, 335-343

Winter A, Ek K, Anderson V (1977) Analytical electrofocusing in thin layers of polyacrylamide gels. Application Note 250 LKBProdukter AB, S6161 25 Bromma, Sweden 